\title{
Citizen Participation and the Rise of Digital Media Platforms in Smart Governance and Smart Cities
}

\author{
Olga Gil, Facultad de Ciencias Políticas, Universidad Complutense de Madrid, Madrid, Spain \\ María E. Cortés-Cediel, Facultad de Ciencias Políticas, Universidad Complutense de Madrid, Madrid, Spain \\ Iván Cantador, Universidad Autónoma de Madrid, Madrid, Spain
}

\begin{abstract}
Many governments and firms do believe that technology can supplant governance and human responsibility. This belief poses the question of who will really benefit from smart cities. This article explores this fundamental question through the study of digital media platforms. The ultimate goal is to understand the link between e-governance and smart city initiatives in our cases of study by testing whether these projects are explicitly for citizens. This article shows how e-platforms represent the use of information and communication technologies with the aim of encouraging citizen participation in decision-making processes, improving information and service delivery, reinforcing transparency, accountability, as well as credibility. Thirteen digital media platforms are surveyed, mostly in cities across countries. These e-platforms raise implementation challenges for both firms and policy makers, and new research opportunities for scientist to build up new research and to experiment with the aim to make the benefits for citizens wider and the participatory dimension stronger.
\end{abstract}

\section{KEYWORDS}

Citizen Participation, E-Platforms, E-Participation, E-Governance, G2B, G2C, G2G, Smart Cities, Smart Government

\section{INTRODUCTION}

Managing urban areas is one of the most important development challenges of the $21^{\text {st }}$ century $-54 \%$ of the world population is living in cities, a proportion that is expected to increase to $66 \%$ by 2050 , as stated in the UN World Urbanization Prospect 2014.

The management of urban areas includes new actions on infrastructures, energy sustainability, natural environment, education, health care, and public safety, to name a few. However, challenges including raising demand for resources, organization and management complexity, make cities main sources of congestion, pollution and waste, exacerbating a variety of socio-economic problems, such as poverty, unemployment, transport, and criminality.

Both the ideas of a smart city and smart government have been conceived as approaches to address such complex urban problems. The smart city and smart government approaches make use 
of Information and Communication Technologies (ICT) with the aim of increasing the interactivity, quality, and efficiency of urban services, reducing costs and resource consumption, and improving the interactions between government, citizens and businesses (Alawadhi et al., 2012). Smart city and smart government, however, are also commonly presented as if technology could supplant governance and human responsibility.

In this work, the authors review the rise of digital media platforms in e-governance, analyzing application cases and existing e-platforms for government-to-citizen (G2C), citizens-to-government $(\mathrm{C} 2 \mathrm{G})$, government-to-business (G2B), and government-to-government $(\mathrm{G} 2 \mathrm{G})$ services. The authors hypothesize that citizens to government would be a less developed mode of e-governance in digital media platforms, which is later confirmed for our set of cases. Thirteen digital media platforms for smart governments and smart cities are compared, including Better Reikjavik in Iceland, Fix My Street, Open Street Map and Small Business Research Initiative in UK, Linea Verde in Spain, Madame la Maire, J'ai un idée in Paris, Billiji, New Urban Mechanics, and Youth Boston in Boston city, Sharing Car Seoul, Peta Jakarta in Indonesia, Blockpooling in Singapore, and Ushahidi in Kenia. For each of the above-mentioned e-service categories, the authors analyze which platforms accommodate better. This will allow to pursue an in-depth comparison of e-platforms that will be later summarized in Table 1. The researchers also find outliers among the cases analyzed. Those outliers include digital platforms mostly focused on business to government and business to citizens, or hybrid services -including both.

The work proceeds as follows. In the next section, definitions are provided, starting with a brief explanation of e-governance, describing its main stakeholders and their interactions, as well as e-platforms. Then, the authors introduce concepts of citizen participation. Later on, the rise of digital media platforms in smart cities and smart governments analyzing the scope of thirteen existing e-platforms is addressed. The presented typology allows the researchers to give strong examples that

Table 1. Findings and comparisons among e-platforms

\begin{tabular}{|c|c|c|c|c|c|c|c|c|c|c|}
\hline & & & $\begin{array}{l}\text { Citizen } \\
\text { control }\end{array}$ & $\begin{array}{c}\text { Delegated } \\
\text { Power }\end{array}$ & $\begin{array}{l}\text { Partnership or } \\
\text { collaboration }\end{array}$ & Placation & Consultation & Informing & Therapy & $\begin{array}{l}\text { Manipula } \\
\text { tion }\end{array}$ \\
\hline E Platform & City/Country & $\begin{array}{l}\text { Platform } \\
\text { type }\end{array}$ & & & & & & & & \\
\hline Better Reikjavik & Reikjavik, Iceland & $G 2 C, C 2 G$ & & & & & & & & \\
\hline Fix My Street & UK & $\begin{array}{c}B 2 G, G 2 C, \\
C 2 G\end{array}$ & & & & & & & & \\
\hline Open Street Map & UK & $\mathrm{C} 2 \mathrm{C}$ & & & & & & & & \\
\hline $\begin{array}{l}\text { Small Business } \\
\text { Research } \\
\text { Initiative }\end{array}$ & UK & $G 2 B, B 2 G$ & & & & & & & & \\
\hline Linea Verde & $\begin{array}{l}\text { Five cities in } \\
\text { Spain }\end{array}$ & $B 2 G$ & & & & & & & & \\
\hline Billiji & Seoul, Korea & $\mathrm{G} 2 \mathrm{C}, \mathrm{C} 2 \mathrm{C}$ & & & & & & & & \\
\hline $\begin{array}{l}\text { New Urban } \\
\text { Mechanics }\end{array}$ & Boston, USA & $\mathrm{G} 2 \mathrm{C}, \mathrm{C} 2 \mathrm{G}$ & & & & & & & & \\
\hline Youth Boston & Boston, USA & $G 2 C, C 2 G$ & & & & & & & & \\
\hline $\begin{array}{l}\text { Sharing City } \\
\text { Seoul }\end{array}$ & Seoul, Korea & $\mathrm{C} 2 \mathrm{C}$ & & & & & & & & \\
\hline Peta Jakarta & Indonesia & $G 2 C, C 2 G$ & & & & & & & & \\
\hline Blockpooling & Singapore & $\mathrm{G} 2 \mathrm{C}, \mathrm{C} 2 \mathrm{C}$ & & & & & & & & \\
\hline
\end{tabular}


platforms are explicitly for citizens, and thus, to draw a clearer link between e-governance and the smart city. The researchers show the typology is useful for further comparative and applied endeavours for both researchers and practitioners, to widen the scope and the quality of future works. Together with a final discussion, a comparative table showing levels of participation in the platform covered is presented. Finally, the conclusions wrap up the article pinpointing the link between governance and smart city initiatives and how the different projects are actually for citizens.

\section{DEFINITIONS}

The definition of smart city differs among disciplines, and has evolved over time. Chourabi et al. (2012) identify eight critical factors of smart city initiatives: 1) management and organization, 2) technology, 3) economy, 4) built infrastructure, 5) natural environment, 6) people and communities, 7) policy context, and 8) governance, which, with the use of ICT, should be accountable, responsive, and transparent, allowing collaboration, data exchange, service integration, and communication.

Among these factors, (smart) governance can be considered as the core and most important challenge of smart cities initiatives (Chourabi et al., 2012). Governance refers to a new form of governing where a network of public and private actors share the responsibility of defining policies, and regulating and providing public services. Examples of these actors -commonly referred to as stakeholders- are government agencies, citizens, markets, and organizations.

Figure 1 depicts the general functions of such stakeholders, and the relationships between them. The figure also shows possible links between e-governance and smart city initiatives.

In the late 1980s, the concept of governance gained momentum. This happened as a response to the citizens' demand for transparency and good management in public administration, which faced a crisis of legitimacy. Actors within the institutions realized the need for openness and considered new forms of governing and management.

Hence, in 1992, in its "Governance and Development" report, the World Bank pioneered the introduction of governance in the field of economic development, by identifying several target areas, namely the public-sector management, accountability, legal framework for development, and information and transparency. The report included experiences and best practices in each area, aiming for a more transparent and efficient way of governing.

Figure 1. The three main governance stakeholders and their relationships

\section{Government}

Legitimate political aggregator

of collective action and provider of public services
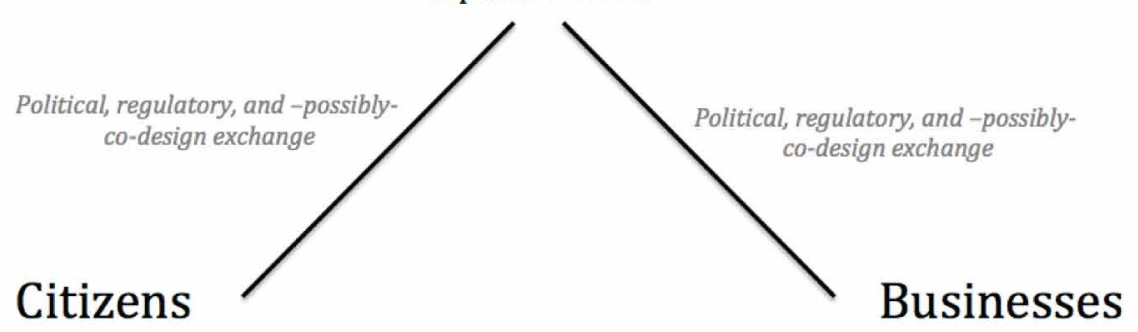

Co-producers, co-creators

Articulators of norms and values, suppliers of workforce

Commercial \& Co-design exchange
Providers of goods and services, jobs and taxes 
In 2001, the European Union published a white paper aimed to bring citizens closer to the European institutions. This entailed encouraging strategies to consolidate governance, by means of initiatives and grants.

In this context, with the consolidation of the Web and social media, the goal of efficient implementations of governance models has brought the adoption of ICT, originating the so-called electronic governance (or e-governance) frameworks.

E-governance has been defined as the application of ICT in the interactions of government with citizens and businesses -e.g., delivery of services, exchange of information, communication, and transactions-, and in internal government operations, aiming to simplify and improve democratic, business and governmental aspects of governance (Backus, 2001).

The number of e-governance solutions has increased remarkably in recent years, providing the involved stakeholders with a wide array of e-services between them. These solutions can be classified as government-to-citizens (G2C), government-to-businesses (G2B), and government-to-government (G2G) e-services, in addition to other cases, such as C2G, B2G, and B2C.

E-governance approaches, however, have been increasingly examined and questioned. Many critics have claimed that technological possibilities rather than user needs have determined too often the design of online public services (Verdegen \& Verleye, 2009). In reaction to this, the need for (more) user-centered e-governance services became more prominent. Hence, progress has to be done on the development of approaches that not only allow for more efficient e-services, but also increase the users' satisfaction and engagement (Dawes, 2008).

For the purpose of this work, digital media platforms will be defined following O'Reilly (2010), whereby government "provides [through ICT) resources, sets rules, and mediates disputes, but allows citizens, nonprofits, and the private sector to do most of the heavy lifting," thereby empowering the people, unleashing social innovation, and reinvigorating (...) democracy."

The motivation of this work is to understand the consequences of different e-governance approaches, looking into cases of platforms with direct or potential link with smart city initiatives. Our ultimate goal is to understand the link between e-governance and smart city initiatives in our cases of study, and test whether these projects are explicitly for citizens. In order to understand better the array of e-services and their e-governance implications the authors present thirteen digital platforms selected in different cities and smart governments across different countries. These digital media platforms have one dimension in common: their capacity for potential or actual changes in public policies.

The choice of analyzed application cases has been dependent upon three bases: 1) testing e-governance approaches, 2) choosing relevant digital media platforms that were all in place in early 2016, and 3) including cases that could be example of innovation across cities and countries in order to reap the benefits of possible innovations worldwide. As such, the authors selected the following thirteen cases of study, including Better Reikjavik in Iceland, Fix My Street, Open Street Map and Small Business Research Initiative in UK, Línea Verde in Spain, Madame la Maire, J'ai un idée in Paris, Billiji, New Urban Mechanics, and Youth Boston in Boston city, Peta Jakarta in Indonesia, Blockpooling in Singapore, and Ushahidi in Kenia.

\section{E-GOVERNANCE}

The public sector and consequently the e-governance domain are complex, and involve a variety of stakeholders. In this context, an individual may belong to several groups and play multiple roles, e.g., she could be a service user, a citizen, and an employee in a business. Rowley (2011), for example, identifies twelve e-government stakeholder roles. The different interests, objectives and benefits of target stakeholders entail dominant characteristics of e-governance services. Simplifying the framework to three principal stakeholders, namely government, citizens and businesses, in this 
work the authors focus on four major, commonly accepted categories of e-governance that reflect the relationships existing between the above stakeholders:

- Government-to-citizens (G2C): e-governance aims to provide citizens with a variety of online information and e-services in an efficient and cost-effective manner, and to strengthen the relationship between government and citizens using ICT. G2C services allow citizens to access government documents (e.g., legislations and regulations), make transactions (e.g., payment of taxes and city utilities), and perform bureaucratic tasks (e.g., changes of address, and application for facilities and grants);

- Citizens to Government (C2G): e-governance aims to provide the citizens with e-platforms with the purpose of sharing distributed information or collaborating in public policy formulation. In a two-way communication, $\mathrm{C} 2 \mathrm{G}$ services allow citizens to message directly to public administrators, send remote electronic votes, propose, discuss and vote public initiatives;

- Government-to-businesses (G2B): e-governance aims to facilitate interaction between the government and corporate bodies and organizations of the private sector with the purpose of providing businesses information and advice on e-business best practices. G2B services allow entrepreneurs to access online information about legislations and regulations, and relevant forms needed to comply with governmental requirements for their business (e.g., corporate tax filing and government procurement).

Finally, government-to-government $(\mathrm{G} 2 \mathrm{G})$ e-governance facilitates the online non-commercial interaction between government organizations, departments and authorities with the purpose of reducing costs, e.g. derived from paper clutter, excessive communications, and unnecessary staffing.

Other categories could also be considered, such as business-to-government (B2G) and businessto-citizens (B2C).

Regarding the above categories of e-government services, the authors advance the hypothesis that $\mathrm{C} 2 \mathrm{G}$ is a less develop mode of e-governance in digital media platforms for smart cities. In the next two sections, the researchers show how the main e-governance models are related to citizen participation. The authors first outline introductory definitions about citizen participation, and then, thirteen real digital media platforms are analyzed in the light of the four e-governance models.

\section{CITIZEN PARTICIPATION}

In recent years, sociologists, political scientists and economists have observed a decline in levels of public confidence in public institutions. Distrust and disaffection among the citizens are prone in many countries. Opening the administration to citizens via digital media platforms has been suggested and experimented as a way to regain legitimacy. In scenarios of growing disaffection, citizen participation might be an instrument through which the population has a greater capacity to monitor and perform functions from control to government. Thus, citizen participation would be the procedure that allows a society to be involved in decision-making within day-to-day policies or actions. Two of the models of citizen participation with a greater relevance in the literature on participation refer 1) to the citizen's involvement (Arnstein, 1969), and 2) on the interaction between the citizen and the administration (OECD, 2001).

Citizen participation is one of the most contended issues in political science topics, and most studied by the social sciences. There is a lack of consensus about what type of participation is appropriate or even why participation should be encouraged (Campos, 2010). In practice, governments can invite citizens to participate by including them in urban development policies, as they can do the opposite, discouraging them and avoiding their concerns. Another remarkable debate is who can participate, and in which resources (public or private) a citizen has to participate. 
Defining citizen participation has not been an easy task within literature (Roberts, 2004). First, it may refer to different actions by different people (Pateman, 1970). Citizen participation can also be understood as the intervention of civil society in the public sphere (Cunill, 1991). Other authors define participation as the process in which citizens' issues, needs and values are incorporated into government and corporate decision-making (Creighton, 2005). Roberts (2004) points out that citizen participation is the process in which members of a society, that is, those who are not members of the government, share power with public managers in areas such as decision making on actions relevant to the community. In this same Roberts' vein, and from the urban planning school, come works such as Peng, and Bugs et al., showing how Internet GIS offers potential for public participation and decision making providing the general public with data, analysis tools, and fora to explore knowledge, express opinion and discuss issues (Peng, 2001, Bugs et al., 2010).

For the purpose of this work, the authors will adopt Roberts' definition: citizen participation as the process in which members of a society, that is, those who are not members of the government, share power with public managers in areas such as decision making on actions relevant to the community. The researchers chose such definition because, being specific, allows the researchers to incorporate in the analysis a wide variety of cases of digital media platforms, which is the result of their interest in understanding how governance changes and evolves, not just how government changes. This definition of participation would also include cases in the emerging field of self-organization of movements and activist groups, cases having an impact on urban planning and development, as well as other areas of public policy. However, the selection of cases has not been done focusing just in these emerging and promising types of cases (i.e., tactical activism). Roberts' definition is coherent with Arnstein's qualification of citizen involvement, that distinguishes among citizen control, delegated power, partnership or collaboration, placation, consultation, informing, therapy and manipulation. Thus, merging both approaches the research shows an elaborated comparison. This comparison is presented before the conclusions, in Table 1, as a tentative framework that allows for wider comparisons with a bigger set of cases that could be combined with more refined in-depth case studies.

\section{E-INFORMATION, E-CONSULTATION AND E-PARTICIPATION}

Government-to-citizen e-services can be categorized in terms of the degree or level of interaction between the government and the citizens, distinguishing among information, consultation, participation and co-design (Coleman, 2008; OECD, 2011).

At the e-information level, government and city websites provide information on policies and programs, laws and regulations, budgets, and other issues of public interest. Governments and cities also offer software tools -such as email subscription lists, online newsgroups, and web forums- for the dissemination, and timely access and use of public information and services.

At the e-consultation level, governments offer online consultation (a.k.a. e-voting) mechanisms and tools, which present citizens with choices about public policy topics, allowing for the deliberation in real time, as well as the access to archived audios and videos of public meetings. With these mechanisms and tools, citizens are encouraged to contribute to government consultation. In this context, digital media platforms may allow citizens to be informed about discussions and others' opinions on consulted issues that could affect their lives. Increasing the value of the information for the citizen could help city governments to obtain more citizens' votes, and improve its citizen-centered decision- and policy-making.

At the e-participation level, local governments intend to incorporate citizens into decision-making processes, in most cases by means of participatory budgeting. For such purpose, they provide online participation platforms where citizens can propose, discuss, give feedback, and vote for initiatives aimed to solve or improve a wide range of situations and problems in different aspects of a city. 


\section{DIGITAL MEDIA PLATFORMS FOR CITIZEN PARTICIPATION AND GOVERNANCE}

Following the presented categories of governance e-services, in this section, the authors propose a number of particular application cases of e-governance, and for each of them, the researchers identify existing digital media platforms, and the citizen participation level it entails. The purpose of the work in this section is twofold; first of all, to test whether these projects are explicitly for citizens, and secondly, very related, to what extent open decision-making processes -or planning processes when this is the case- involving participation of citizens and community groups ensure meaningful effects on the decision-making process, as suggested by Peng (2001). The cases analysed will allow to test whether serious applications of Web 2.0 continue to be sparse, as argued by Rinner, Keßler and Andrulis (2008), or on the contrary, examples start to abound showing that e-platforms are illustrations of such applications on a global scale.

\section{Our Choice of Platforms was Pursued in Early 2016}

- Better Reikjavik (Iceland): This is an online consultation forum where citizens are given the chance to present their ideas on issues regarding services and operations of the City of Reykjavík. Anyone can view the open forum and registered users who approve the terms of participation in the forum. Registered users participate in the consultation forum by presenting their ideas, viewing other users' ideas, arguing issues, voicing their opinion, and rating ideas and argumentations supporting or opposing them. Each month, the five top rated ideas are processed in the appropriate standing committee. In addition, the top-rated idea in each category is addressed in the appropriate standing committee every month; the categories are tourism, operations, recreation and leisure, sports, human rights, art and culture, education, transportation, planning, administration, environment, welfare, various. The city, however, has a specific purview, so not all the ideas presented are necessarily addressed;

- Fix My Street (UK): This is a platform that allows reporting problems to the city government. The platform functions as follows: first, by entering a nearby postcode, or street name and area in the United Kingdom; secondly, by locating a problem on a map of the area; thirdly, by entering details of the problem; and finally, by sending the information to the council on the behalf of the citizen or resident. This is a B2G platform. There exists a FixMyStreet Professional version that is announced as "the one-stop street reporting service for councils", and it allows integrating the platform with the council system for end-to-end report fulfillment;

- Open Street Map (UK): This is a platform that allows creating and providing free geographic data, such as street maps, to anyone. This project is backed by the OpenStreetMap Foundation, an international not-for-profit organization. Its goal is to encourage the growth, development and distribution of free geospatial data and to provide geospatial data for anyone to use and share. The foundation organizes the conference State-of-the-map, with annual editions from 2007 worldwide;

- SBRI - Small Business Research Initiative (UK): This is a platform that connects public sector challenges with new ideas from industry. The goal of this G2B platform is to support companies to generate economic growth, and to work together towards improvement in achieving government objectives. SBRI has been organized competitions of business ideas from 2009 to 2016 in fields covering a wide range of topics from new vaccines for global epidemics to childcare and elderly provision;

- Línea Verde (Spain): Developed in 2009, this platform allows citizens, business and residents to report problems about urban equipment to local governments in some Spanish cities via a mobile application. The web platform also includes local regulations, legislation, environmental news, subsidies an agenda, and monthly campaigns. The platform, created as a B2G project, has 
been adopted as an outsourced service in cities such as Calafell, Ciudad Real, Huelva, Laredo and Segovia;

- Madame la Maire, J'ai un idée (Paris): In this digital platform, residents of Paris are invited to propose ideas and projects for the city, according to thematic tags. These ideas can be further discussed, enriched and reshaped in a collaborative manner by all participants. The first campaign hosted on the platform was a participatory budget. This budget allowed all Parisians to propose a project, at the scale of the district or the entire capital. Each year, Parisians are invited to vote on the proposed projects, with a budget of 480 million euros over the entire mayor mandate (5\% of the investment budget);

- Billiji (Seoul): This was a Korea-based web/app platform for peer-to-peer lending and sharing. It offered a secure and convenient platform for users to share or lend their items to others. Billiji was headquartered at the College of Business Administration in Korea Advanced Institute of Science, in Seoul;

- New Urban Mechanics (Boston): The Mayor's Office of New Urban Mechanics (MONUM) in Boston was formed in 2010. MONUM research and design projects tackle topics from civic engagement to city infrastructure to education. The MONUM team works on civic innovation, and it has extended its definition from increasing government efficiency to improving the experience and well-being of residents and visitors. The members of the team explore, experiment and evaluate civic innovation projects across departments and throughout Boston city. One such example is the Engagement Lab, which aims to find new ways to create democratic action. The MONUM team seeks to create an open culture of civic action and dialog. Its members focus on trying new programs that engage and empower the community, making government more transparent through data and storytelling, finding new ideas and talent through local research and design communities, using analog as well as digital tools to engage with people, and getting more people involved, with a focus on quality conversations;

- Youth Boston (Boston): Youth Lead the Change is a platform for participatory budgeting process where young 12 to 25 years-old Bostonians decide how to spend $\$ 1,000,000$ of the City's budget. The Mayor's Youth Council runs this process and shares rule-making authority with youth organizations across the city. It works in three steps: first, ideas are collected; secondly proposals are developed; and lastly, ideas are voted upon in June every year since 2014. Voting locations are located at schools and transport stations across Boston. Students can vote online if they are enrolled at Boston Public Schools. Five projects have been completed since its inception, and another thirteen are in progress, assigned to a city department with a dedicated project manager;

- Sharing City Seoul (Korea): This platform seeks to mitigate social problems by promoting shared use of both public and private resources, while boosting civic engagement and supporting local businesses. Seoul local government started the Sharing City Seoul initiative on September 2012, along with a plan to implement sharing projects closely related to the lives of citizens and to establish and broaden the foundation for sharing. Seoul local government sees the Sharing City Seoul initiative as a social innovation measure designed to create new economic opportunities, to restore reliable relationships, and to reduce waste of resources with a view to resolving economic, social, and environmental problems in urban areas. It has done so with the aid of a share hub platform, online and offline;

- Peta Jakarta (Indonesia): This is an open source flood map for the city of Jakarta, Indonesia, which experiences severe flooding on an annual basis. It offers up-to-date information, critical for relief and response efforts to be targeted and effective. PetaJakarta combines information about the extent and locations of disasters, such as floods, which is key to reduce harmful impacts and maximizing resilience. PetaJakarta enables the Jakarta Emergency Management Agency to see locations of flooding across the entire city at a glance, meaning less time for data collection and more time for response. The PetaJakarta.org website combines 
different data -from social media reports to river gauge measurements- to provide the best possible source of information for decision-making during flooding. Its map combines citizen reporting, social media, government flood alerts and sensor data to provide flood information for residents and the government;

- Blockpooling (Singapore): This is a social network for communities, which was set up in 2013 with a grant from the government to enable neighbors to share belongings, offer and ask for services. The platform aims to strengthen communities in Singapore and making more efficient use of resources. A 'lend and borrow' function uses postcodes to help people to find others in their neighborhood who have items they are willing to share or have a thing they need to borrow. The same functionality lets people connect with others in their block, seek out advice, invite them to events (users are encouraged to host events for neighbors), and inform them about activities such as building work or parties that might inconvenience them;

- Ushahidi (Kenya): This platform was developed to map reports of violence in the country after the post-election violence in 2008. Since then, the platform states that thousands have used its crowdsourcing tools to raise their voice. A further development, headquartered in Nairobi, provided software and services to government sectors and civil society to help improving the bottom up flow of information. They aim to provide people with easy communication with organizations and governments, which in turn may more effectively respond to their communities' needs.

At the time of this empirical research, these platforms where outliers and very advanced in terms of digital support for participation in cities. Moreover, other digital media platforms have been developed, and might be incorporated into a further study.

Next, for each of the considered e-governance categories -namely G2C, C2G, G2B and G2G e-services-, the authors present a number of application cases addressed by digital platforms for the corresponding stakeholders. The researchers also categorize the analyzed digital platforms in such application cases.

\section{G2C and C2G Digital Platforms}

Following the description of the digital platforms, in this section the authors analyze which particular platforms may fall within the label of government-to-citizens digital platforms (G2C). For this purpose, the following application cases are identified:

- Providing citizens with government notifications and services: In this case, digital platforms may take citizens' profiles into account to provide personalized services. Besides, they may consider the provision of context-aware e-services, which may have potential interest in certain situations where, among other aspects, periods of time (e.g., a particular tax collection campaign), locations (e.g., citizen's neighborhood), and personal events (e.g., parties, pending birth of a citizen's child, hiring of neighbors) are used. For this case, the authors identify three platforms among those studied: Linea Verde in Spanish Cities, which has an agenda and includes information on legislation and local news, Youth Boston, a web portal for participatory budgeting among the youth in Boston city, and Peta Jakarta, which uses social media for civic co-management during monsoon flooding in Jakarta, Indonesia. The three cases are explicitly for citizens;

- Keeping the government informed about the citizens' problems, concerns and opinions: In this case, e-consultation and e-participation platforms, as well as external social media, such as online social networks and microblogging systems, are used. These digital media platforms might function as tools of anticipatory policy-making, allowing the government to anticipate to future problems (Guston, 2014). The following digital media platforms are suited within this case: Better Reikjavik in Iceland, New Urban Mechanics, Fix My Street in UK, Linea Verde in Spain, 
Open Street Map in UK, Madame la Maire, J'ai un idée in Paris, Peta Jakarta in Indonesia, and Ushahidi in Kenia. Besides showing that cases under this label are explicitly for citizens, certain features of the platforms also involve participation of citizens and community groups, and it could be further test in future works if those platforms ensure meaningful effects on the decision making process, following Peng (2001);

- Assisting the citizens in finding relevant proposals, individuals and associations: In an e-participation platform, the number of initiatives and discussions may be overwhelming, and there is a need to rank those more relevant for a particular citizen based on her preferences. This can be done according to personal interests explicitly declared though votes, forums, or implicitly expressed by means of online comments and social links. The following digital media platforms are suited within this case: Better Reikjavik in Iceland, Youth Boston in Boston city, Madame la Maire, J'ai un idée in Paris, Linea Verde in several Spanish cities;

- Sharing distributed information or collaborating in public policy formulation: This is a particular C2G case. Among the selected platforms, a possible best sample of such clear-cut formulation of digital media platform is Ushahidi, in Kenia. Ushahidi was developed to map reports of violence after the post-election violence in 2008. Since then, the crowdsourcing tools enabled by the platform have served to raise citizens' voice. This is an example of a citizen team that developed as business software and services provider to help improve the bottom up flow of information. Recent work by Cantador et al. (2017) aims to obtain more meaningful participatory budgeting information from e-platforms for both citizens and governments. This work focuses on the development of platforms' capacity to better adapt to citizens and residents needs through personalized recommendations.

\section{G2B Digital Platforms}

Once government-to-citizens application cases have been presented, the researchers turn on government-to-business digital platforms (G2B). In government-to-business e-governance, the researchers identify the following application cases that are further explained below: 1) finding business partners in government and city services, 2) informing companies and 3) online support in legal and administrative consultancy:

- Finding business partners in government and city services: Here the goal is the connection of the government with the industry. The target could be industry partners for the realization of initiatives and actions, at multiple dimensions, e.g., technological, commercial, financial, social, and political- or the companies -which may need the collaboration of other partners for particular tasks of their businesses and projects (oriented to the citizens or the government). The following digital media platforms would fall within this case: Billiji in Korea, Fix My Street in UK, Línea Verde in Spain, Blockpooling in Singapore, Sharing Car Seoul in Korea, and Small Business Research Initiative in UK;

- Informing the companies about events that involve or are related with their businesses and the government agencies: Such as public calls, initiatives and projects, grants and subventions, and exhibitions, fairs, seminars and conferences. Here digital media platforms would suggest business opportunities according to implicit government and citizens' needs, especially at municipal level. No digital media platform was reported to address these services at the time the empirical work was carried out;

- Providing the companies with online support in legal and administrative consultancy: On government laws, regulations and procedures. This could be done in a personalized way, according to their business profiles, and at either local, regional, national or international level. No digital media platform was reported to address these services at the time the empirical work was carried out. However, Línea Verde in some Spanish cities offers a service answering 
environmental questions in 24 hours and it has a related platform allowing for legal and administrative consultancy.

\section{G2G Digital Platforms}

Government-to-government e-services aim to support better coordination and cooperation between government agencies, departments and employees. A common situation is that each governmental organization usually has developed its own information systems in isolation. Effective and efficient (electronic) communication, however, is needed to get commitment and to support decision-making, which is complicated due to the large number of involved stakeholders, such as politicians, information managers, administrative departments, and ICT teams.

In addition to (certain) lack of interoperability, governmental organizations are usually characterized by rigid and cryptic, vertical hierarchies (Weber, 1946), which has been shown to generate citizens' disaffection. Initiatives such as the New Public Management, Open Government, and Smart Government aim to provide more transparency and flexibility, and thus restore the confidence on the public sector.

The following application cases would fall within the scope of improved G2G-services. Here, nonetheless, the authors did not have empirical cases among those selected:

- Enhancing the government electronic interoperability: Here the researchers would include effective digital media platforms that aggregate and transfer knowledge from/towards different agents;

- Improving the management of human resources in government: Here the authors would include digital media platforms showing public officials who could perform particular tasks or take certain government positions. This could be achieved if government employees have an academic and professional profile associated, as well as information about work availability and restrictions;

- Providing government employees with recommendations of professional events: Digital media platforms could generate personalized suggestions of available job positions, new promotion examinations, and seminars and courses offered by government agencies. The employees' profiles may be the same as those presented in the case of e-management of human resources in government.

The authors also found outliers among the cases analyzed. Those outliers included platforms mostly focused on business-to-government (B2G) and business-to-citizens (B2C) services, or hybrid services, including both. These categories have to be added after the studies the researchers analyzed, following the fact that the range of cases came out wider than expected. Components of these two categories were found in the following digital platforms: Billiji in Korea, Fix My Street in UK, Línea Verde in Spain, Blockpooling in Singapore, Sharing Car Seoul in Korea, and Ushahidi in Kenia. These platforms where relevant for the degree of innovation creating new markets, markets with more transparency, and novel ways to address policy making.

Table 1 summarizes the findings and the comparison among e-platforms in the context of the definitions provided in the section citizen participation, in particular, regarding Arnstein ladder of participation.

As a general discussion, the comparison of the cases allows understanding and defining the link between e-governance and smart city initiatives. First of all, as the authors wanted to test whether data shows that platforms are explicitly for citizens, making a contribution to the social sciences on the current debate in the fields of economy, political science and sociology by showing that participation does increases in qualitative and quantitative ways in the cases studied. Moreover, the work also shows evolution in e-platforms enhancing the participation experience, with dramatic improvements beyond the role of information receiver. This strongly compares with the fact that most platforms provided 
only one way information a few years ago (Conroy and Evans-Cowley, 2006). Therefore, the authors find an important leap forward, with two-way feed-back as standard in the cases studied. The data collected on the cases have shown that involving more stakeholders in the planning process might result in more policy recommendations. It could also be studied in further works, whether involving more stakeholders results in more implementation, as suggested by Goodspeed (2008).

Secondly, the comparison of the cases also show that platforms might connect huge amounts of information in engaging and interactive ways. Thirdly, the empirical cases also make contributions to urban planning by showing that e-platforms are useful to engage the public as social tools involving community members in context, contributing in a fundamental way to debates started by Bugs et al. (2010) and Peng (2001). The empirical cases also show how technology is used not only as substitute for traditional approaches but also as a way for new approaches to citizen participation, adding new evidence to the debate suggested by Casey and Li (2014).

On technological grounds, there are promising opportunities on personalization of e-governance services. There are also promising streams of joint research on how computer systems could facilitate citizen engagement. Furthermore, we still lack shared knowledge on digital media platforms among technologists, policy makers, researchers and practitioners, and the researchers expect this has been a modest contribution to this kind of collaborative research.

\section{CONCLUSION}

In this article, the ultimate goal is to understand the link between e-governance and smart city initiatives in our cases of study, and test whether these projects are explicitly for citizens. Many governments and firms, as shown by Paudyn $(2014,2016)$, believe that technology can supplant governance and human responsibility. This work shows, however, that platforms might be explicitly for citizens.

This work starts with the definitions, a brief explanation of e-governance, describing its main stakeholders and their interactions and concepts of citizen participation. The authors also hypothesize that citizens-to-government services would be a less developed mode of e-governance in digital media platforms, which has been confirmed for our set of cases. Later on, the rise of digital media platforms in smart cities and smart governments is analyzed from the point of view of the stakeholders and their interactions. In doing so the researchers also find that there were outliers among the cases analyzed. These outliers included digital platforms mostly focused on business-to-government and business-to-citizens, or hybrid services -including both.

The authors have reviewed the rise of digital media platforms in e-governance, analyzing application cases for G2C, G2B and G2G services. To do so, the authors explored thirteen digital media platforms for smart governments and smart cities, including Better Reikjavik in Iceland, Fix My Street, Open Street Map and Small Business Research Initiative in UK, Linea Verde in Spain, Madame la Maire, J'ai un idée in Paris, Billiji, New Urban Mechanics, and Youth Boston in Boston city, Sharing Car Seoul, Peta Jakarta in Indonesia, Blockpooling in Singapore, and Ushahidi in Kenya. For each e-service category, the authors depict what platforms among those selected and studied accommodate better. The researchers depict types of e-governance and citizen participation among the proposed cases. The researchers show this typology and examples are useful for further work by both researchers and practitioners. This typology does help us to show variations in complexity and dimensions of the thirteen platforms. Further works are needed in order to better understand the variations in complexity, dimension and ecologies of evolving e-platforms. Even though one way to address this complexity has been to take the definition of e-platforms from O'Reilly (2010), which temporarily solves the problem, the researchers are aware of the challenge coming from continuous innovation, in ICT, policies, policy transfer and from policy imitation (Gil, 2016).

The limitations of this analysis have to do with the relatively small set of digital platforms (thirteen in total). However, our study has generated enough conclusions aimed to improve the 
capacity to analyze digital media platforms in comparative perspective, from both the perspectives of e-governance and citizen participation.

There are remaining issues to address, and among the current limitations of e-governance services, and participation through e-platforms the authors find more work is needed on feedback in G2C and $\mathrm{C} 2 \mathrm{G}$, active listening, the level of participation the -in many cases- outweighed participation of the most educated, the need to incorporate technology to processes, and the current limited the possibilities offered to add intelligence to digital media platforms.

As further work, on participatory grounds, more work is needed to understand what drives large number of people to participate in e-platforms, and where does their motivation for increased participation lie, following the work by Neis, Zielstra and Zipf (2012). Finally, more evidence is needed on the results of participation on digital media platforms across a bigger set of cases as solutions to challenges of the real world.

\section{ACKNOWLEDGMENT}

The comments of three anonymous reviewers have been extremely useful to arrive to this stage in the work published. The authors are indebted to them for their time, their work, ideas and corrections. This work has been supported by Grant CITADEL H2020 Empowering Citizens to Transform European PubLic Administrations. H2020 Framework Program (under GA 726755, running from 1/9/2016 to 1/9/2020) directed by Daniel Diaz-Fuentes, University of Cantabria --This is a pan European project with the innovation Basque firm TECNALIA as general coordinator. This work has has also been supported by the Spanish Ministry of Economy, Industry and Competitiveness (TIN2016-80630-P). 


\section{REFERENCES}

Alawadhi, S., Aldama-Nalda, A., Chourabi, H., Gil-García, J. R., Leung, S., Mellouli, S., . . Walker, S. 2012. Building understanding of smart city initiatives. In Proceedings of the 2012 International Conference on Electronic Government (pp. 40-53).

Asiaone. (n.d.). Blockpooling, Retrieved from http://www.asiaone.com/singapore/facebook-neighbors

Backus, M. (2001). E-Governance and Developing Countries: Introduction and Examples (Technical report). The Hague, The Netherlands: The International Institute for Communication and Development.

Better Reikjavik. (n.d.). Retrieved from https://betrireykjavik.is

Billiji. (n.d.). Retrieved from http://billiji.com

Bugs, G., Granell, C., Fonts, O., Huerta, J., \& Painho, M. (2009). An Assessment of Public Participation GIS and Web 2.0 Technologies in Urban Planning Practice in Canela, Brazil. Cities (London, England), 27(3), $172-181$. doi:10.1016/j.cities.2009.11.008

Campos, E. (2010). Participación ciudadana en el ámbito municipal. Reflexiones teórico-empíricas y prácticas participativas.

Cantador, I., Bellogín, A., Cortés-Cediel, M. E., \& Gil, O. (2017). Personalized recommendations in e-participation: Offline experiments for the 'Decide Madrid' platform. In Proceedings of the 1st International Workshop on Recommender Systems for Citizens. doi:10.1145/3127325.3127330

Casey, C., \& Li, J. (2014). Web 2.0 Technologies and Authentic Participation: Engaging Citizens in Decision Making Processes. Cyber Behavior: Concepts. In Methodologies, Tools and Applications (pp. 767-793). Hershey, PA: IGI Global.

Chourabi, H., Nam, T., Walker, S., Gil-García, J. R., Mellouli, S., Nahon, K., \& Scholl, H. J. et al. (2012). Understanding smart cities: An integrative framework. In Proceedings of the 45th Hawaii International Conference on System Sciences (pp. 2289-2297). IEEE.

Coleman, S. (2008). Doing IT for themselves: Management versus autonomy in youth e-citizenship. In W. Lance Bennett (Ed.), Civic life online: Learning how digital media can engage youth (pp. 189-206). Cambridge, MA: The MIT Press.

Conroy, M. M., \& Evans-Cowley, J. (2006). E-participation in Planning: An Analysis of Cities Adopting on-line citizen Participation Tools. Government and Policy, 24(3), 371-384. doi:10.1068/c1k

Creighton, J. L. (2005). The public participation handbook: Making Better Decisions through Citizen Involvement. John Wiley \& Sons.

Cunill, N. (1991). Participación ciudadana. Caracas: CLAD.

Dawes, S. S. (2008). The evolution and continuing challenges of e-governance. Public Administration Review, 68(s1), S86-S102. doi:10.1111/j.1540-6210.2008.00981.x

European Union. (2001). European Governance - A White Paper. Retrieved from http://europa.eu/rapid/pressrelease_DOC-01-10_en.htm

FixMyStreet. (n.d.). Retrieved from https://www.fixmystreet.com

Gil, O. (2016). Análisis de Políticas Públicas en Perspectiva Comparada. In E. A. de la Política Mikel Barreda \& L. Ruiz (Eds.), Huygens (pp. 463-480). Barcelona.

Goodspeed, R. C. (2008). Citizen Participation and the Internet in Urban Planning. Unpublished master's thesis for the Degree of Master of Community Planning, University of Maryland, College Park.

Guston, D. H. (2014). Understanding 'anticipatory governance.' Social Studies of Science, 44(2), $218-242$. doi:10.1177/0306312713508669 PMID:24941612

Línea Verde. (n.d.). Retrieved from http://www.Lineaverdemunicipal.com 
Neis, P., Zielstra, D., \& Zipf, A. (2012). The Street Network Evolution of Crowdsourced Maps: OpenStreetMap in Germany 2007-2011. Future Internet., 4(1), 1-21. doi:10.3390/fi4010001

New Urban Mechanics. (n.d.). Retrieved from https://www.boston.gov/departments/new-urban-mechanics

O’Reilly, T. (2010). Government as a Platform. In D. Lathrop \& L. Ruma (Eds.), Open government: Collaboration, transparency, and participation in practice. O'Reilly Media.

Open Street Map. https://www.openstreetmap.org/about

Organisation for Economic Co-operation and Development (OECD). (2001). Citizens as partners: Information, consultation and public participation in policy-making. OECD Publishing.

Paris Madame la Maire. (n.d.). J'ai un idée. Retrieved from https://idee.paris.fr

Pateman, C. (1970). Participation and democratic theory. Cambridge University Press. doi:10.1017/ CBO9780511720444

Paudyn, B. (2014). Credit Ratings and Sovereign Debt: The Political Economy of Creditworthiness through Risk and Uncertainty. Springer. doi:10.1057/9781137302779

Paudyn, B. (2017). Financial Engineering through risk uncertainty: The performative political economy of credit worthiness and its self-generative effects for credit rating agencies. International Political Sociology.

Peerby. (n.d.). Retrieved from https://www.peerby.com

Peng, Z.-R. (2001). Internet GIS for public participation. Environment and Planning. B, Planning \& Design, 28(6), 889-905. doi:10.1068/b2750t

Peta Jakarta. (n.d.). Retrieved from https://petajakarta.org

Rinner, C., Keßler, C., \& Andrulis, S. (2008). The use of Web 2.0 concepts to support deliberation in spatial decision-making. Computers, Environment and Urban Systems, 32(5), 386-395. doi:10.1016/j. compenvurbsys.2008.08.004

Roberts, N. (2004). Public deliberation in an age of direct citizen participation. American Review of Public Administration, 34(4), 315-353. doi:10.1177/0275074004269288

Rowley, J. (2011). e-Government stakeholders - Who are they and what do they want? International Journal of Information Management, 31(1), 53-62. doi:10.1016/j.ijinfomgt.2010.05.005

Sharing City Seoul. (n.d.). Retrieved from http://english.sharehub.kr/what-is-a-sharing-city-seoul

Small Business Research Initiative in UK. (n.d.). Retrieved from https://sbri.innovateuk.org

Ushahidi. (n.d.). Retrieved from https://www.ushahidi.com/about

Verdegem, P., \& Verleye, G. (2009). User-centered e-Government in practice: A comprehensive model for measuring user satisfaction. Government Information Quarterly, 26(3), 487-497. doi:10.1016/j.giq.2009.03.005

Weber, M. (1946). Bureaucracy. In From Max Weber: Essays in sociology (pp. 232-235).

World Bank. 1992. Governance and Development. Washington, DC, April 1992. http://documents.worldbank. org/curated/en/604951468739447676/Governance-and-development

World Urbanization ProspectUN. (2014). Retrieved from https://esa.un.org/unpd/wup

Youth Boston. (n.d.). Retrieved from http://youth.boston.gov/youth-lead-the-change 
Olga Gil is Full professor (accredited) whose interests cover public policy, local government, technology, regulation, and digital transformation in cities. Dr. Gil is currently a member of the EU project CITADEL (2016-2020): Empowering Citizens to Transform European Public Administrations, under the H2020 Framework Programme. Call H2020-SC6-CULT-COOP-2017-2017. Proposal 726755. Gil is member of the The Smart Cities and Smart Governments Research-Practice Consortium based at the Center for Technology in Government, University at Albany. Doctor Gil has recently published a book on smart cities in comparative perspective in Spanish: ¿Quién Gobierna las Ciudades?, comparing Shanghai, Iskandar, cities in Japan, New York, Amsterdam, Málaga, Santander and Tarragona. In 2017 Gil published chapters in two books with world specialists in Palgrave and Elsevier, on cities coordination mechanisms, and Chinese smart city plans, and the most recent, on Coordination Mechanisms and Network Performance has been published in the Journal Croatian and Comparative Public Administration. At the moment she is working on E-Governance in Smart Cities: New Opportunities for Recommender Systems, together with Iván Cantador (Escuela Politécnica, Universidad Autónoma de Madrid) and Elicia Cortés (Facultad de Ciencias Políticas, Universidad Complutense de Madrid).

María E. Cortés-Cediel has received her Bachelors in Law and Political Science and Public Administration from Universidad Autónoma de Madrid, Madrid, Spain. She received the MSc in Government and Public Administration from Universidad Complutense de Madrid in 2017.

Iván Cantador received a PhD degree in Computer Science in 2008 at Universidad Autónoma de Madrid (UAM), Spain. During his doctoral studies, he was a research consultant at the Knowledge Media Institute at the Open University (UK), and a research visitor at University of Southampton (UK). After earning his PhD, he worked for one year as a research associate at University of Glasgow (UK), and as a postdoctoral research visitor at the Free University of Bozen-Bolzano (Italy). Currently, he is a senior lecturer at UAM. In the last 5 years, he has supervised $3 \mathrm{PhD}$ and $5 \mathrm{MSc}$ theses. He has participated in 2 EU/FP6 IP projects, and in 12 Spanish projects, being the principal investigator of 3 of them. Dr. Cantador has co-authored over 70 publications in journals and conferences on Recommender Systems, Information Retrieval, and Semantic Web. He serves regularly as reviewer and scientific committee member in venues of the aforementioned fields, including prestigious conferences such as RecSys, SIGIR, WWW, CIKM, Hypertext, UMAP, ISWC, ESWC, AAAI and IJCAI. He has also been member of international conference and workshop organizing committees, and has been part of the editorial board of a special issue at ACM TIST journal. 